
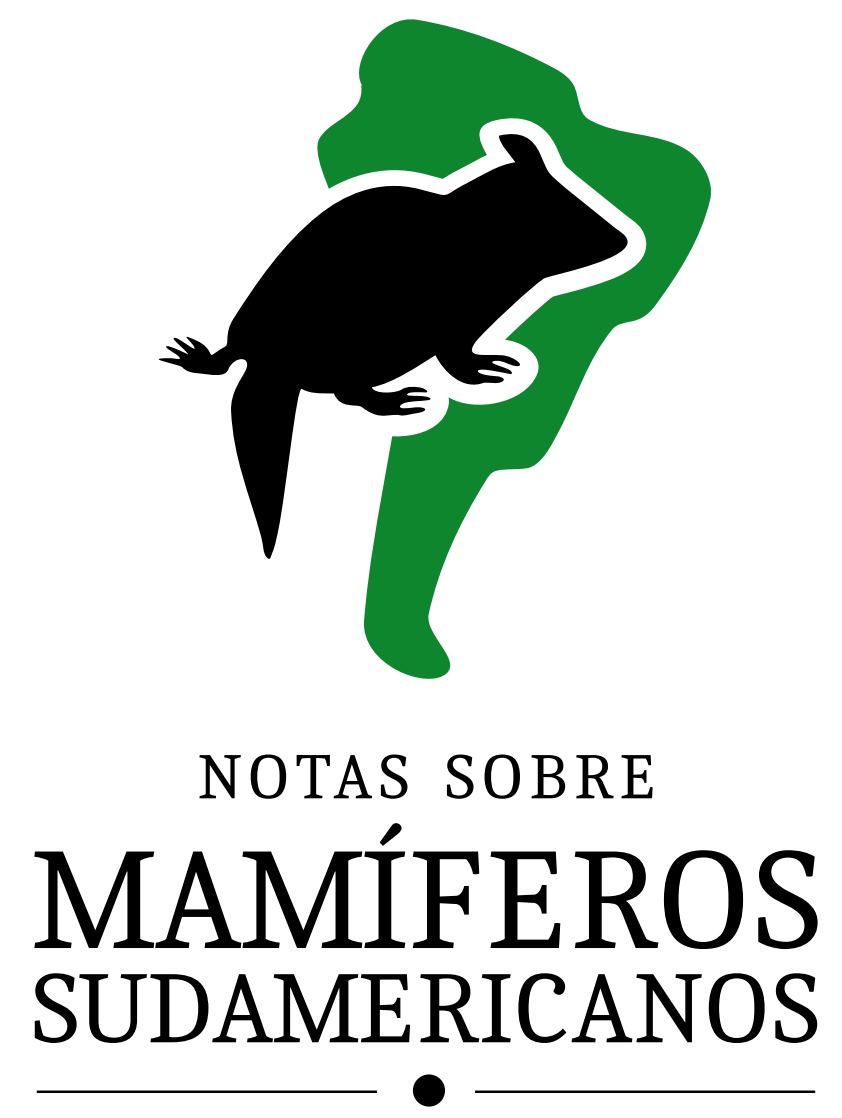

NOTAS SOBRE

MAMÍFEROS

$\underline{\text { SUDAMERICANOS }}$ 


\title{
Evidence of an infanticide in black-horned capuchin monkeys (Sapajus nigritus) in an Atlantic Forest remnant in Argentina
}

\author{
Gimena A. Illia (1, 2), Martín Kowalewski (2, 3) and Luciana I. Oklander (1, 2)
}

(1) Instituto de Biología Subtropical (IBS), Universidad Nacional de Misiones (UNaM)- CONICET, Misiones, Argentina. (2) Consejo Nacional de Investigaciones Científicas y Técnicas (CONICET). (3) Estación Biológica Corrientes, Museo Argentino de Ciencias Naturales “Bernardino Rivadavia”, Corrientes, Argentina. [correspondence: gimena.illia@gmail.com]
Citation: Illia, G. A., M. Kowalewski, \& L. I. OKLander. 2021. Evidence of an infanticide in black-horned capuchin monkeys (Sapajus nigritus) in an Atlantic Forest remnant in Argentina. Notas sobre Mamíferos Sudamericanos 3:e21.2.6.

\begin{abstract}
An infanticide is a rare event but has important impact in primate populations. The black-horned capuchin monkey, Sapajus nigritus, is a native species from the Atlantic Forest. Previous reports of infanticide in this species are explained with the 'sexual-selection' hypothesis, and occur in large groups and after a dominant male replacement. Here we provide evidence of a new case of infanticide by a non-identified member of a wild group of $S$. nigritus, in a remnant of the Atlantic Forest under anthropogenic disturbance. Our study group (30-35 individuals) overlapped its home range with other species' groups in an isolated forest fragment (570 ha). This primate overcrowding in a small area may have increased social intolerance and aggression. In this regard, this infanticide event may be associated to a non-adaptive explanation such as the social pathology hypothesis.
\end{abstract}

Key words: anthropogenic disturbance, Atlantic forest, infanticide, social pathology hypothesis.

\section{RESUMEN - Evidencias de infanticidio en el mono caí negro (Sapajus nigritus) en un remanente de Bosque Atlántico Argentino}

Los infanticidios son eventos raros que tienen gran impacto en las poblaciones de primates. El mono caí negro, Sapajus nigritus, es una especie nativa del Bosque Atlántico. Los registros previos de infanticidios en la especie han sido explicados por la teoría de selección sexual, y ocurren en grandes grupos luego del recambio de los machos dominantes. En este trabajo, describimos un nuevo caso de infanticidio producido por un miembro no identificado de un grupo silvestre de $S$. nigritus, en un remanente del Bosque Atlántico que se encuentra bajo disturbio antrópico. El grupo de estudio (de 30-35 individuos) tiene un área de acción que se superpone con grupos de monos de otras especies en un fragmento de bosque aislado de 570 ha. Esta superpoblación de primates en un área pequeña podría resultar en un aumento de la intolerancia y agresiones. De esta forma, el infanticidio podría ser explicado de manera no-adaptativa como la teoría de la patología social.

Palabras clave: bosque Atlántico, disturbio antrópico, infanticidio, teoría de la patología social.

Infanticides, the killing of an infant by a conspecific, have been reported in several groups of mammals (Parmigiani \& Vom Saal 1994; Palombit 2015). These events are of interest due to their direct impact on reproductive success, and the conse- 
quences on the demographic structure of the population (Valderrama et al. 1990). Amongst primates, infanticides have been reported in more than 50 of both old and New World species (Gursky-Doyen 2011; Alvarez et al. 2015; Palombit 2015; Kane \& Gnepa 2016; Knott et al. 2019).

These infanticides are mostly explained under the 'sexual-selection' hypothesis, in which an adult male kills unweaned offspring of rival males, thus accelerating the mother's next ovulation, in which the infanticidal male has an increased probability of siring the next infant (Hrdy 1979; van Schaik \& Janson 2000). However, there are at least six other hypotheses that can explain this behavior (Hrdy 1979; Sommer et al. 2018). One of these hypotheses, the 'social pathology', explain that an infanticide can be a non-adaptative event produced by a high rate of aggressions resulting from altered living conditions, such as deforestation or overpopulation (Boggess 1979; Sussman et al. 1994). Examples of this can be observed for high population densities in Thomas langur monkeys (Presbytis thomasi Collett, 1893) (Sterck 1997, 1999), for a non-adaptive behavior resulting from a human-induced disturbance in Hanuman langur monkeys (Semnopithecus entellus Dufresne, 1797) (Curtin \& Dolhinow 1978; Boggess 1984), and for a high rate of aggressions caused by anthropogenic disturbance and habitat degradation in chimpanzees (Pan troglodytes Blumenbach, 1776) (Williams et al. 2008) and Tibetan macaques (Macaca thibetana Milne-Edwards, 1870) (Berman et al. 2007).

The Atlantic Forest is a subtropical forest reduced to less than 100,000 $\mathrm{km}^{2}$ (approximately 7\% to its original coverage) distributed in Brazil, Paraguay and Argentina (Tabarelli et al. 2005; Marques \& Grelle 2021). The black-horned capuchin monkey, Sapajus nigritus Goldfuss, 1809, is an arboreal primate endemic to the Atlantic Forest, distributed across south and southeastern Brazil and northern Argentina (Fig. 1A). The species is considered as "Near threatened" by the IUCN (Martins et al. 2019) with declining populations, but in Argentina it is categorized as "Vulnerable" (Tujague et al. 2019).

Although infanticides are rare events that are more difficult to witness in free-ranging primates, there are already a few reports in the genus Cebus (Valderrama et al. 1990; Rose 1994; Fedigan 2003; Manson et al. 2004; Brasington et al. 2017). To date, only four cases of observed or suspected infanticide have been witnessed in Sapajus nigritus (Izar et al. 2007; Ramírez-Llorens et al. 2008), and there are no reports of infanticide in any other Sapajus species (Table 1). Here we describe a new case of infanticide by a non-identified member of a wild group of $S$. nigritus in a remnant of the Atlantic Forest under anthropogenic disturbance.

Since August 2019, a group of black-horned capuchin monkeys is being studied in a fragment of the Atlantic Forest located in the Yacutinga private reserve, Misiones province, Argentina (latitude -26.58; longitude -54.07; Fig. 1B). The reserve comprises 570 ha of forest surrounded by the Iguazú river and farms, and combines conservation and tourism activities. In this forest fragment there are two identified groups of $S$. nigritus (although we are still reevaluating the area, and we suspect there could be a third), and two groups of black and gold howler monkeys (Alouatta caraya Hum- 
boldt, 1812). The study group is composed by 30-35 individuals and its home range is 200 ha, overlapping this area with one of the A. caraya groups. The home range of the $S$. nigritus study group overlaps with tourism activities and worker cabins (maintenance staff and guides). Thus, monkeys are habituated to tourists but do not interact directly with them. The group has been followed up monthly during five consecutive days for parasitological studies, with $480 \mathrm{~h}$ in the field (until February 2020, when a nation-wide lockdown was established in Argentina to prevent further spread of COVID-19). When the infanticidal attack took place, behavior of individuals was recorded opportunistically.

On December 19, 2019, at 17:20 h, intense vocal threats and screams were heard among the individuals in the group, and lasted for a few seconds. The vocalizations, after a few minutes of silence, were heard again. The group was 60 meters away from one of the principal tourist trails. After this event, the individuals of the group were calm, did not present alarm signals due to the presence of researchers, and continued moving while foraging. However, an adult female remained in the area vocalizing with an unweaned infant 4-12 months age (Baldovino \& Di Bitetti 2008) (Fig. 2). No visible wounds were seen by binocular observation on the adult female or the infant. Next to the female was an adult male, which after recognizing the presence of observers, decided to abandon the female and leave in the same direction in which the rest of the group was moving to. After a few minutes of observation, the infant fell and was held between lianas. The female descended to hold the infant again, which remained immobile all the time, and in an attempt to force the infant onto her back, the female dropped the infant to the ground. Despite the presence of the observers, she descended to grab the infant. A few minutes later, the female dropped the body again and descended to the ground climbing to the same tree she was before, carrying the infant in one arm. At dusk ( 19:40 h), the female remained alone, vocalizing and repeating the same movements on the branches. Already at night $(20: 30 \mathrm{~h})$, researchers left the place leaving the female still vocalizing. The rest of the group stayed away in the hours following the aggression. The next day, before dawn $(\sim 5: 00 \mathrm{~h})$, observers returned to the area but the female was already gone and there was no trace of the dead infant. Three hours later, the rest of the group was found approximately 1.1 kilometers from the site where the female remained the day before (Table 2). During the next two months after this event, no aggressive behavior was observed again between group members. No demographic changes in the study group have been registered during and after the infanticide. Furthermore, while we did not observe intra-group agonistic behaviors (threat or aggressions) in the months after the infanticide, we registered two threats and aggressions before. On August 2019, an A. caraya's group was resting when the study group showed up, and both groups began threatening each other until the howler group left the zone. On November 19, 2019 intragroup aggressions were observed between adult males and females during dawn.

Ramírez-Llorens et al. (2008) reported an infanticide and two additional infant disappearances after a dominant male replacement in $S$. nigritus in a continuous 
ecosystem from the Iguazú National Park in Argentina. Including the report in Brazil (Izar et al. 2007), all the infanticides described seem to fit with the 'sexual-selection' hypothesis, and they all occur after a modification in the demographic structure of the group. In all reports, infanticides occurred in large groups of more than 30 individuals. Particularly, the population of Iguazú National Park split in two new groups associated with a replacement of the dominant male in the original group, following with the disappearance of infants (Ramírez-Llorens et al. 2008; Janson et al. 2012). When groups are larger than expected, they face greater living costs than smaller ones, and group cohesion decreases (Lehmann et al. 2007). In large groups of $S$. nigritus, group fission is frequently an event after a dominant male replacement (Janson et al. 2012; Scarry $\&$ Tujague 2012), in part as a potential counterstrategy to infanticides (Ramírez-Llorens et al. 2008; Scarry \& Tujague 2012). But, group fission and individual dispersal may also involve high costs in saturated and/or fragmented environments (Majolo et al. 2008).

Although all infanticidal attacks in $S$. nigritus have been associated with the 'sexual-selection' hypothesis, and there is not enough information to date to completely discard that the infanticide case reported here could be explained with this hypothesis, our observations are more consistent with the 'social pathology' hypothesis. Our study group lives in an isolated forest fragment surrounded by farms characterized by anthropogenic disturbances (crop-livestock systems), that prevent the dispersal of monkeys beyond the study site. In this scenario, we believe that environmental pressure due to the high number of individuals in the group, and sharing the area with other primate groups (capuchins and howlers) in a small and isolated forest fragment, interfere with counterstrategies of infanticidal attacks such as group fission, previously registered in continuous environments as the Iguazú National Park (Ramírez-Llorens et al. 2008; Janson et al. 2012).

\section{ACKNOWLEDGMENTS}

The authors thank Charlie and María del Rosario Sandoval, and all their workers for allowing monitoring the monkey's groups in their reserve. To Macarena Penskofer

and Emilia Taroni for their invaluable help monitoring the monkeys and recording data in the field. This study was funded by Primate Conservation Inc. 


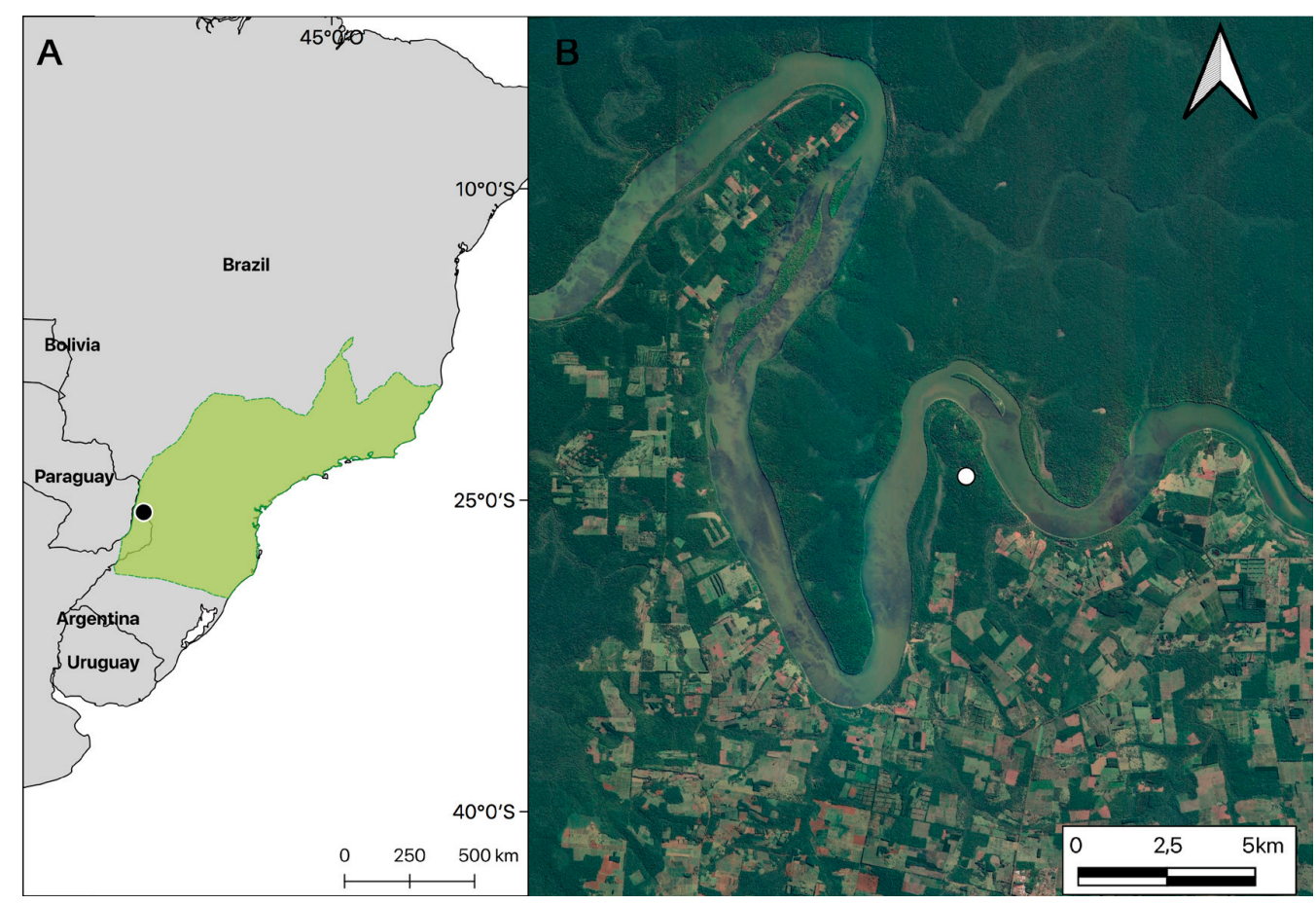

Figure 1. A) Black-horned capuchin monkey Sapajus nigritus distribution range from IUCN database (Martins et al. 2019); B) study site in an Atlantic Forest fragment (latitude -26.58; longitude -54.07) located in the north of Misiones province, Argentina.

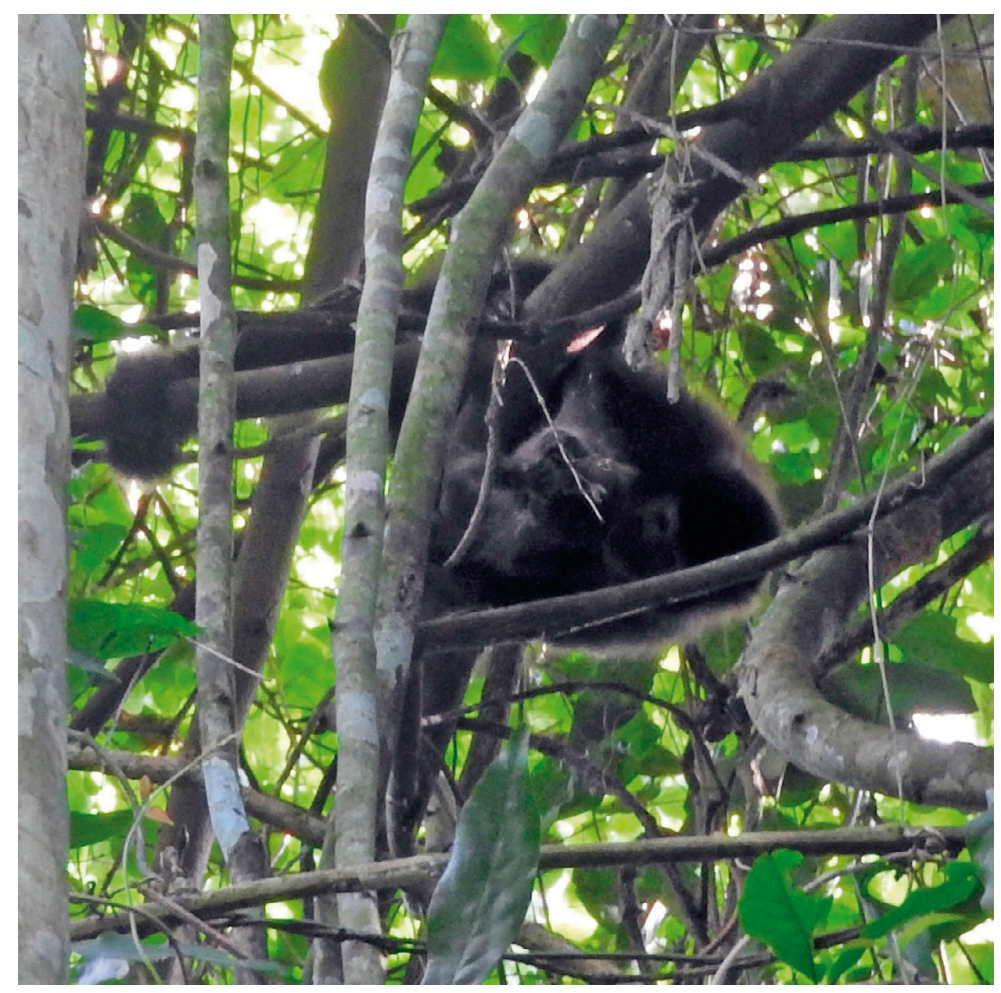

Figure 2. Adult female of black-horned capuchin monkey, Sapajus nigritus, with the immobile infant. 
Table 1. Observed or suspected infanticide reports in Sapajus nigritus. Each site with their size in ha in parenthesis. ${ }^{1}$ Izar et al. 2007; ${ }^{2}$ Ramírez-Llorens et al. 2008; ${ }^{3}$ Present study.

\begin{tabular}{|c|c|c|c|c|c|c|c|}
\hline $\begin{array}{l}\text { Site } \\
\text { (size in ha) }\end{array}$ & Report & $\begin{array}{l}\text { Intergroup } \\
\text { interactions }\end{array}$ & $\begin{array}{l}\text { Demographic } \\
\text { changes }\end{array}$ & Infanticidal & $\begin{array}{l}\text { Group } \\
\text { Size } \\
\text { (individuals) }\end{array}$ & $\begin{array}{l}\text { Sampling } \\
\text { method }\end{array}$ & $\begin{array}{l}\text { Hyphotesis } \\
\text { proposed }\end{array}$ \\
\hline $\begin{array}{l}\text { Jaraguá State } \\
\text { Park, Sao Pablo, } \\
\text { Brazil } \\
(500 \text { ha })^{1}\end{array}$ & Infanticide & Not reported & $\begin{array}{l}\text { Dominant male } \\
\text { replacement }\end{array}$ & $\begin{array}{l}\text { New dominant } \\
\text { male }\end{array}$ & 30 & Not reported & Sexual-selection \\
\hline \multirow{2}{*}{$\begin{array}{l}\text { Iguazú National } \\
\text { Park, Misiones, } \\
\text { Argentina } \\
(67,720 \text { ha })^{2}\end{array}$} & Infanticide & \multirow[t]{2}{*}{ S. nigritus } & \multirow{2}{*}{$\begin{array}{l}\text { Group fission. } \\
\text { Dominant male } \\
\text { replacement }\end{array}$} & $\begin{array}{l}\text { New dominant } \\
\text { male }\end{array}$ & \multirow[t]{2}{*}{37} & \multirow[t]{2}{*}{ Focal sampling } & \multirow[t]{2}{*}{ Sexual-selection } \\
\hline & $\begin{array}{l}\text { Two } \\
\text { suspected } \\
\text { reports }\end{array}$ & & & $\begin{array}{l}\text { New dominant } \\
\text { male (assumed) }\end{array}$ & & & \\
\hline $\begin{array}{l}\text { Yacuntinga, } \\
\text { Misiones, } \\
\text { Argentina ( } 570 \\
\text { ha) }\end{array}$ & Infanticide & $\begin{array}{l}\text { S. nigritus } \\
\text { and } A \text {. caraya }\end{array}$ & Not observed & Not observed & $30-35$ & Ad libitum & Social-pathology \\
\hline
\end{tabular}

Table 2. Summary of recorded behaviors of individuals before and during the infanticide.

\begin{tabular}{|c|c|c|}
\hline Date (2019) & Hour & Observations \\
\hline August & & Threats between study group and A. caraya group. \\
\hline 19 November & 05:40 & Intragroup aggressions between adult females and males. \\
\hline \multirow[t]{6}{*}{19 December } & $\begin{array}{l}17: 20- \\
17: 22\end{array}$ & Vocal threats and screams heard. \\
\hline & & $\begin{array}{l}\text { An adult female was in a } 15 \text { meters branch of Guatambú (Balfourodendron riedelianum), vocalizing } \\
\text { with an unweaned infant. The rest of the group was already leaving. An adult male was next to the } \\
\text { female, but left the place, with the presence of the researchers. }\end{array}$ \\
\hline & $17: 30$ & $\begin{array}{l}\text { The infant fell for first time and was held between lianas. The adult female descends to hold the } \\
\text { infant again. In an attempt to force the infant onto her back, the infant fell to the ground for second } \\
\text { time. }\end{array}$ \\
\hline & 18:00 & The infant fell to the ground for third time. \\
\hline & $19: 40$ & The female remained alone vocalizing and repeating the same movements on the branches. \\
\hline & $20: 30$ & Researchers left the place, leaving the female still vocalizing. \\
\hline \multirow[t]{2}{*}{20 December } & $\sim 05: 00$ & The female was already gone and the infant body was not found. \\
\hline & $08: 15$ & The rest of the group was found $1.1 \mathrm{~km}$ from the attack. \\
\hline
\end{tabular}

\section{LITERATURE CITED}

Alvarez, S., A. Di Fiore, J. Champion, M. S. PavelKa, J. PÁez, \& A. Link. 2015. Male-directed infanticide in spider monkeys (Ateles spp.). Primates 56:173-181.

Baldovino, M. C., \& M. S. Di BitetTr. 2008. Allonursing in tufted capuchin monkeys (Cebus nigritus): milk or pacifier? Folia Primatologica 79:79-92.

Berman, C. M., J. Li, H. Ogawa, C. Ionica, \& H. Yin. 2007. Primate Tourism, Range Restriction, and Infant Risk Among Macaca thibetana at Mt. Huangshan, China. International Journal of Primatology 28:11231141. 
Boggess, J. 1979. Troop Male Membership Changes and Infant Killing in Langurs (Presbytis entellus). Folia Primatologica 32:65-107.

BogGESS, J. 1984. Infant killing and male reproductive strategies in langurs (Presbytis entellus). Infanticide: comparative and evolutionary perspectives (S. B. Hrdy \& G. Hausfater, eds.). Aldine Publishing Company, New York.

Brasington, L. F., E. C. Wikberg, S. KaWamura, L. M. Fedigan, \& K. M. Jack. 2017. Infant mortality in white-faced capuchins: The impact of alpha male replacements. American Journal of Primatology 79:e22725.

CuRTin, R., \& P. Dolhinow. 1978. Primate social behavior in a changing world. American Scientist 66:468475.

Fedigan, L. M. 2003. Impact of male takeovers on infant deaths, births and conceptions in Cebus capucinus at Santa Rosa, Costa Rica. International Journal of Primatology 24:723-741.

GURSKY-Doyen, S. 2011. Infanticide by a male spectral tarsier (Tarsius spectrum). Primates 52:385-389.

HRDY, S. B. 1979. Infanticide among animals: A review, classification, and examination of the implications for the reproductive strategies of females. Ethology and Sociobiology 1:13-40.

IzAR, P., E. D. Ramos-DA-Silva, B. D. De-Resende, \& E. B. OtTon. 2007. A case of infanticide in tufted capuchin monkeys (Cebus nigritus). Mastozoologia Neotropical 14:73-76.

Janson, C., M. C. Baldovino, \& M. Di Bitettr. 2012. The group life cycle and demography of Brown Capuchin Monkeys (Cebus [apella] nigritus) in Iguazú National Park, Argentina. Long-Term Field Studies of Primates (P. M. Kappeler \& D. P. Watts, eds.). Springer, Berlin, Heidelberg.

Kane, E., \& F. GNePa. 2016. An Infanticide Attempt After Male Takeover in Diana Monkeys (Cercopithecus diana diana) in Taï, Côte d'Ivoire. African Primates 11:37-40.

KNotT, C. D. eт AL. 2019. Possible male infanticide in wild Orangutans and a re-evaluation of infanticide risk. Scientific Reports 9:7806.

Lehmann, J., A. H. Korstjens, \& R. I. M. Dunbar. 2007. Group size, grooming and social cohesion in primates. Animal Behaviour 74:1617-1629.

Majolo, B., A. DE BoRtoli Vizioli, \& G. Schino. 2008. Costs and benefits of group living in primates: group size effects on behaviour and demography. Animal Behaviour 76:1235-1247.

Manson, J. H., J. Gros-Louis, \& S. PerRY. 2004. Three apparent cases of infanticide by males in wild white-faced capuchins (Cebus capucinus). Folia Primatologica 75:104-106.

Marques, M. C. M., \& C. E. V. Grelle (eds.). 2021. The Atlantic Forest: History, Biodiversity, Threats and Opportunities of the Mega-diverse Forest. Springer International Publishing, Cham.

Martins, J. N. Et al. 2019. Sapajus nigritus: The IUCN Red List of Threatened Species 2019:e. T136717A70614508. https://dx.doi.org/10.2305/IUCN.UK.2019-3.RLTS.T136717A70614508.en.

PaLombit, R. A. 2015. Infanticide as sexual conflict: coevolution of male strategies and female counterstrategies. Cold Spring Harbor Perspectives in Biology 7:a017640.

Parmigiani, S., \& F. S. Vom SAal (eds.). 1994. Infanticide and parental care. Harwood Academic Publishers, Chur, Langhorne.

Ramírez-Llorens, P., M. S. Di Bitetti, M. C. Baldovino, \& C. H. Janson. 2008. Infanticide in black capuchin monkeys (Cebus apella nigritus) in Iguazú National Park, Argentina. American Journal of Primatology 70:473-484.

Rose, L. M. 1994. Benefits and costs of resident males to females in white-faced capuchins, Cebus capucinus. American Journal of Primatology 32:235-248.

SCARRY, C. J., \& M. P. Tujague. 2012. Consequences of lethal intragroup aggression and alpha male replacement on intergroup relations and home range use in Tufted Capuchin Monkeys (Cebus apella nigritus): changes in Capuchin intergroup relations. American Journal of Primatology 74:804-810.

Sommer, V., R. Minocher, \& A. Lowe. 2018. Infanticide. The International Encyclopedia of Anthropology (H. CAllan, ED.). 1st edition. John Wiley \& Sons, Ltd., United Kingdom.

SтеRск, E. H. 1997. Determinants of female dispersal in Thomas langurs. American Journal of Primatology 42:179-198.

STERCK, E. H. M. 1999. Variation in langur social organization in relation to the socioecological model, human habitat alteration, and phylogenetic constraints. Primates 40:199-213.

Sussman, R. W., J. M. Cheverud, \& T. Q. Bartlett. 1994. Infant killing as an evolutionary strategy: Reality or myth? Evolutionary Anthropology: Issues, News, and Reviews 3:149-151. 
TABarelli, L. P. Pinto, J. M. C. Silva, M. Hirota, \& L. BedE. 2005. Challenges and opportunities for biodiversity conservation in the Brazilian Atlantic Forest. Conservation Biology 19:695-700.

Tujague, M. P. et AL. 2019. Sapajus nigritus. Categorización 2019 de los mamíferos de Argentina según su riesgo de extinción. Lista Roja de los mamíferos de Argentina (SAyDS-SAREM, eds.). <http://cma. sarem.org.ar>

ValderRama, X., S. SRikosamatara, \& J. G. Robinson. 1990. Infanticide in Wedge-Capped Capuchin Monkeys, Cebus olivaceus. Folia Primatologica 54:171-176.

VAN SCHAIK, C. P., \& C. H. JANSON (EDS.). 2000. Infanticide by males and its implications. 1st edition. Cambridge University Press.

Williams, J. M., E. V. Lonsdorf, M. L. Wilson, J. Schumacher Stankey, J. Goodall, \& A. E. Pusey. 2008. Causes of death in the Kasekela chimpanzees of Gombe National Park, Tanzania. American Journal of Primatology 70:766-777. 